\title{
Editor's Note: Twisted Legacies: Politics of Authorship
}

The articles in this issue of $D R J$ take up four figures of North American dance in the twentieth century-Anna Sokolow, Franziska Boas, Martha Graham, and Merce Cunningham. These essays shed new light on these artists' legacies and open up new interpretive horizons onto the political, social, authorial, historical, and aesthetic dimensions of their activities. They also "twist" what we thought we knew about these legacies_or, about legacy itself — from their traditionally accepted shapes into ones that are far more historically probing, if also increasingly complex. This is as it should be, and each essay significantly clears the air around a certain topic: they share a certain refreshing quality.

The question of authorship — whether the meaning of this term be literary (as in the artist autobiography), intentional in relation to the meaning of the dance work (its political, social, and memorial meaning), or even the etymological sense of auctoritas (authority in the assertion, misapplication, and/or concealment of intent) - yields new insights into political, social, and aesthetic choreographies. The essays are all strongly based in historical method, although they contain a variety of theoretical reflections as well. The situation of the 1930s and 1940s, in particular, is only susceptible to analysis with a distancing that has permitted the development of critical lenses unavailable to that period, although not for that reason anachronistic.

Hannah Kosstrin's “Inevitable Designs: Embodied Ideology in Anna Sokolow's Proletarian Dances” revisits the form/content divide of the 1930s by re-envisioning the relationship between choreographic form, technical skill in dancing, and ideologically oriented content to be a question of embodiment in the case of Anna Sokolow. Kosstrin reveals much formal detail in important early Sokolow works whose precise features have been thought lost to history and memory. By investigating Sokolow's political affiliations during the 1930s and 1940s, Kosstrin clarifies a historical ambiguity of aesthetics and politics. Toward the end of her life, Anna Sokolow maintained the line imposed by her FBI interrogators of the McCarthy era that in the 1930s she was politically unaffiliated. Kosstrin's research brings clarity to Sokolow's political engagement at a time when her work spoke unequivocally for the downtrodden. Yet, like Jean-Paul Sartre in the immediate post-war period, Sokolow transformed the ontology of communism in a very individual way.

Allana Lindgren's “Civil Rights Strategies in the United States: Franziska Boas's Activist Use of Dance, 1933-1965" examines the pedagogical, dramaturgical and activist contributions of Franziska Boas, a figure who has largely been lost to dance history. Lindgren teases out contradictions in Boas's racial position and explores how anti-racist activism and the reinforcement of white privilege could occasionally go hand in hand. Here, the issue of authority clashes with stated social and political intent. The author grounds herself in critical race theory and critical whiteness studies as well as in extensive archival research to examine how Boas's advocacy of African-American artists functioned in the context of her school at Bolton's Landing and in New York City, her administrative and artistic collaborations with Claude Marchand and Katherine Dunham, and in her later career as an educator in Rome, Georgia. The authority Boas attributed to her own privileged position is one that Lindgren takes up unremittingly in order to re-situate the conundrums of racial

(n)


activism in the legacy of modern dance. In so doing, Lindgren extends the periodization of the Civil Rights Movement from the 1930s to the 1960s.

With the subject of Martha Graham, we enter onto the properly literary terrain of authorship. Victoria Phillips's archival research unveils the textual genesis and publication history of Martha Graham's autobiography, Blood Memory, putting into question the artist's full authorship of this text. While many of the words and formulations of Blood Memory may have been Graham's, the degree to which she herself controlled the ultimate composition of the text and its erasure of important people in her life raises questions about the "authenticity" of Graham's authorship that Phillips addresses. If Graham herself was not fully present in the book's composition, she becomes paradoxically present in Phillips's essay, which sheds unexpected light on her personality in the last years of her life.

While the first three articles are deeply historiographical, sociological, and even to some degree psycho-social, Carrie Noland's article concerns a more contemporary moment than the other three, albeit one with roots in the history and ethos of the avant-garde. "Inheriting the Avant-Garde: Marcel Duchamp, Merce Cunningham, and the Legacy Plan" is a study of legacy not as a historical remainder but as a plan whose driving force, the author reveals, is a theory of the avant-garde from a fully Duchampian perspective. This essay is a critique, in other terms, of a plan for history and hence a reinterpretation of the legacy projected toward the future in that plan. Noland perceives a double impulse in Cunningham's work, allying him with Duchamp, to create the unforeseen, but also to memorialize it. This "archival logic" is shown to operate in the final memorial performances of the Merce Cunningham Dance Company-the Park Avenue Armory Event in New York City in 2011. Noland embeds these performances in what is known as the Legacy Plan itself, as "the archival project of an avant-garde form" ( $\mathbf{p} . \mathbf{X}$ ) to examine the fertile contradictions in preserving the eventful status of avant-garde production.

Throughout this issue, we perceive a dense web of historiographical, sociological, psychosocial, and theoretical analysis redirecting legacies in new directions and toward unexpected shapes, effectively twisting them back into their previously imperceptible configurations. The notion of twisting here is related to clarification and insight rather than to distortion, and, in this sense, there is a deconstructive aspect to these analyses despite, and actually thanks to, their firm basis in archival evidence. Such metacritical reflection on movement in and through history and the turns and returns of historical reflection is a trait I would like to highlight in these deeply historiographical pieces.

A special thanks is extended to Janet and Nils Morgan of the Barbara Morgan archive for allowing permission to publish the cover images of Anna Sokolow by Barbara Morgan.

Mark Franko

Editor, Dance Research Journal 